\title{
Slugs (of Florida) (Gastropoda: Pulmonata) ${ }^{1}$
}

\author{
Lionel A. Stange and Jane E. Deisler ${ }^{2}$

\section{Introduction}

Florida has a depauparate slug fauna, having only three native species which belong to three different families. Eleven species of exotic slugs have been intercepted by USDA and DPI quarantine inspectors, but only one is known to be established. Some of these, such as the gray garden slug (Deroceras reticulatum Müller), spotted garden slug (Limax maximus L.), and tawny garden slug (Limax flavus L.), are very destructive garden and greenhouse pests. Therefore, constant vigilance is needed to prevent their establishment. Some veronicellid slugs are becoming more widely distributed (Dundee 1977). The Brazilian Veronicella ameghini (Gambetta) has been found at several Florida localities (Dundee 1974). This velvety black slug should be looked for under boards and debris in vacant lots and cemeteries. Slugs are not commonly seen or collected because they are active mostly at night and inconspicuous during the day. In Spanish, they are called "babosas" from the verb "babear" (to drool), because of the copious amount of mucus they secrete. Slugs should be preserved in $75 \%$ isopropyl alcohol. It is best to drown them in water overnight in a covered container without air pockets so the bodies will be extended. After drowning they should be washed under running water to remove excess mucus before placing in preservative. Notes on the color of the mucus secreted by the living slug would be helpful in identification.

\section{Biology}

Slugs are hermaphroditic, but often the sperm and ova in the gonads mature at different times (leading to male and female phases). Slugs commonly cross fertilize and may have elaborate courtship dances (Karlin and Bacon 1961). They lay gelatinous eggs in clusters that usually average 20 to 30 on the soil in concealed and moist locations. Eggs are round to oval, usually colorless, and sometimes have irregular rows of calcium particles which are absorbed by the embryo to form the internal shell (Karlin and Naegele 1958). As a result, slug eggs often become more transparent as they grow. As soon as they hatch, young slugs (often lighter in color than adults) are active, crawl and feed if the temperature and humidity conditions are right. It is often several days before any plant injury becomes apparent, because they merely rasp away surface tissues. Slugs, especially young and hungry ones, can lower themselves from plants by mucus threads (Key 1902) that may extend several feet.

1. This document is EENY-087 (originally published as DPI Entomology Circulars No. 197 and 261), one of a series of Featured Creatures from the Entomology and Nematology Department, Florida Cooperative Extension Service, Institute of Food and Agricultural Sciences, University of Florida. Published: June 1999. Revised: April 2004. This document is also available on Featured Creatures Website at http://creatures.ifas.ufl.edu. Please visit the EDIS Website at http://edis.ifas.ufl.edu.

2. Lionel A. Stange and Jane E. Deisler, Florida Department of Agriculture and Consumer Services, Division of Plant Industry, Gainesville, FL.

The Institute of Food and Agricultural Sciences (IFAS) is an Equal Opportunity Institution authorized to provide research, educational information and other services only to individuals and institutions that function with non-discrimination with respect to race, creed, color, religion, age, disability, sex, sexual orientation, marital status, national origin, political opinions or affiliations. U.S. Department of Agriculture, Cooperative Extension Service, University of Florida, IFAS, Florida A. \& M. University Cooperative Extension Program, and Boards of County Commissioners Cooperating. Larry Arrington, Dean 


\section{Identification}

Slugs are easily recognized by their soft, unsegmented bodies, dorsally covered completely or in part by a tough leathery skin (mantle). The head has a pair of upper tentacles bearing eyes, and a pair of shorter, olfactory ones. Positive identification of species often depends on internal anatomy. Color is often used, but considerable variation can occur.

The primitive Veronicellidae family of slugs (here represented by Angustipes ameghini, Leidyula floridana and Vaginula plebeia) is tropical in distribution and possesses several features not found in other slug families. This includes having the eyes on contractile rather than inversible tentacles. In addition, the mantle covers the entire back of the animal and laterally overhangs the narrow foot so that the side walls of the body are hidden. The philomycid slugs have a similar mantle and could be confused with veronicellid slugs. However, differences in breathing pore and anus location can distinguish these two groups of slugs. Philomycid slugs have a breathing pore located anteriorly on the right side of the mantle, and the anus is located anteriorly. In veronicellid slugs no breathing pore is present and the anus is located near the posterior end of the body. The shape of the anus and the flap that covers it offer good generic characters.

\section{Key to Slugs of Florida including Intercepted Species}

1. Mantle covering all of the back of the animal (Figs. 1-6) . . . . 2

1'. Mantle covering only anterior part of the animal (Figs. 11-21) . . . 5

2(1). Breathing pore visible in short slit near anterior right mantle edge (Fig. 1); (Family Philomycidae) ..... Philomycus carolinianus (Bosc)

Length 50 to $100 \mathrm{~mm}$. Albino (Hermann and Dundee 1959) and melanistic forms known but typically yellowish brown with 2 rows of dark spots along back. Feeds on fungi. Found under loose bark and aerial bromeliads. Native: Maine to Florida, west to Iowa and Texas. County records: Alachua, Collier, Jackson, Marion, Volusia.

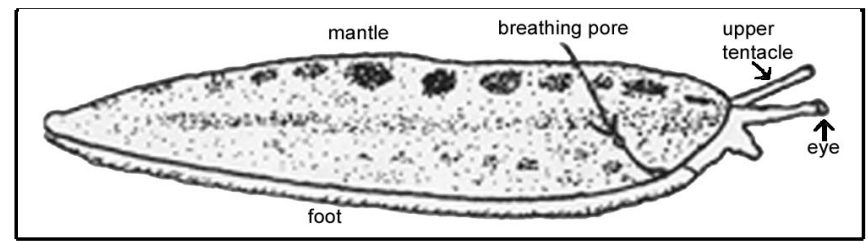

Figure 1. Slug Nomenclature. Credits: Division of Plant Industry

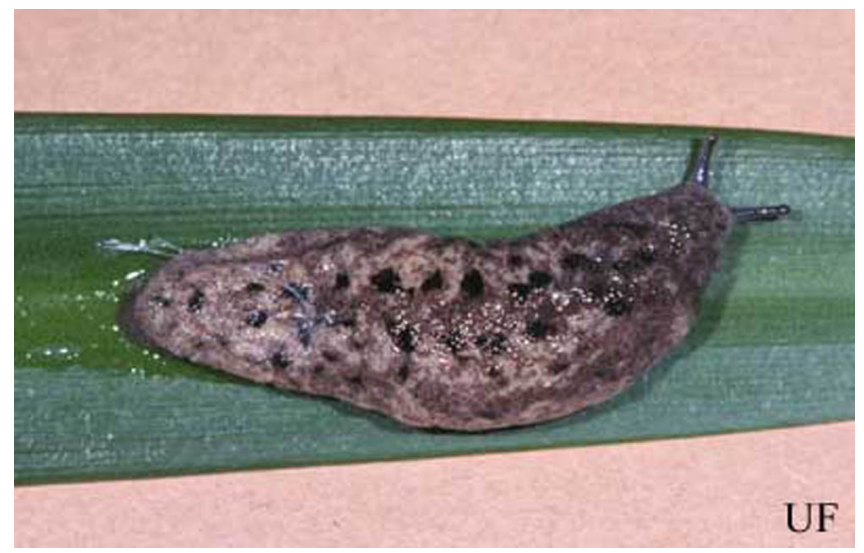

Figure 2. The slug Philomycus carolinianus (Bosc). Credits: Lyle Buss, University of Florida

2'. Breathing pore not visible (Figs. 3, 4); (Family Veronicellidae) .....3

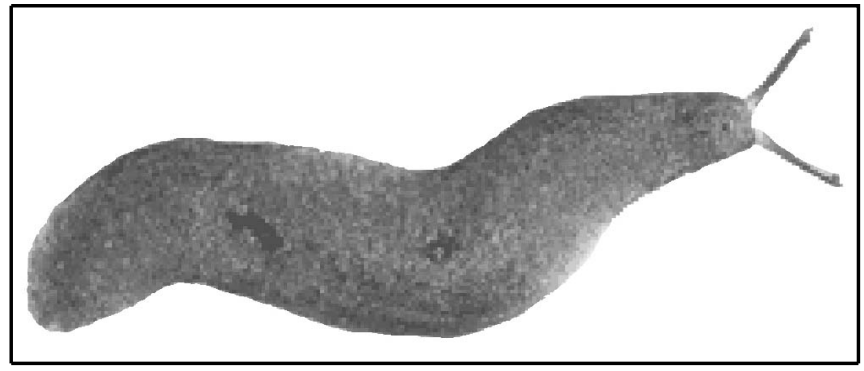

Figure 3. Veronicella ameghini(Gambetta) slug. Credits: Division of Plant Industry

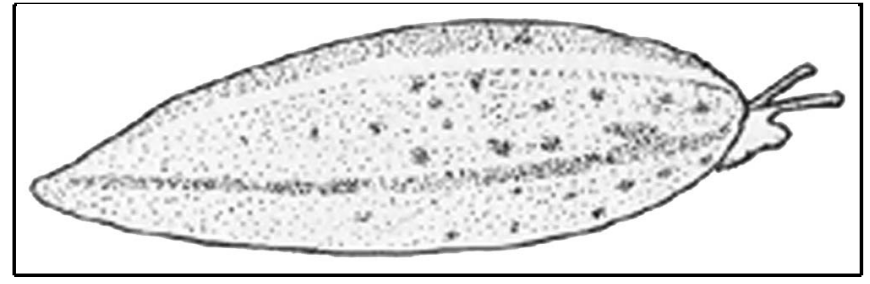

Figure 4. Veronicella floridana (Leidy) slug. Credits: Division of Plant Industry

3(2'). Body velvety black in color (Fig. 5); anus roundish and median in position, usually protected ventrally by dextral flap so superficial crescentic slit is longitudinal (Fig. 6) and normally hidden under end of retracted foot ..... Angustipes (=Veronicella) ameghini (Gambetta) 


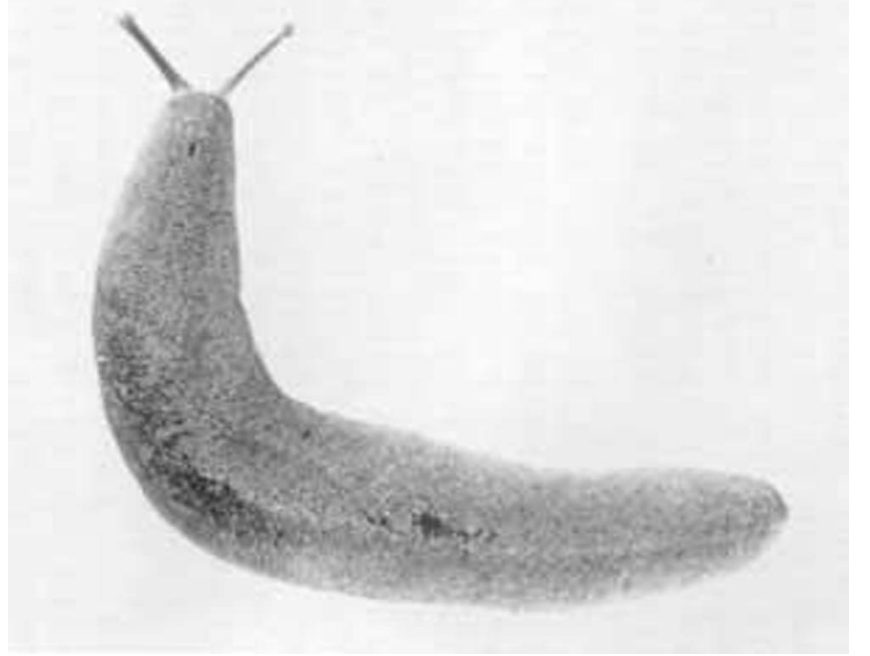

Figure 5. Angustipes ameghini. Credits: Division of Plant Industry

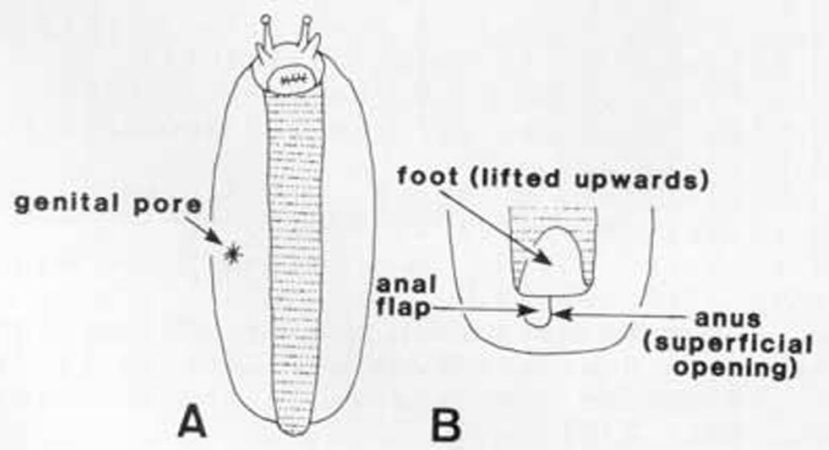

Figure 6. Angustipes ameghini - (A) ventral view, $(\mathrm{B})$ anal view. Credits: Division of Plant Industry

This slug was originally described from Paraguay and first introduced into the United States (Mobile AL, and New Orleans LA) in 1960 (Dundee and Watt 1961). It is now common in the western panhandle of Florida. Records from other parts of Florida (Dundee 1974, 1977) were based on interceptions, but in 1982 this slug was found to be well established in Orange County (Gillmore 1982). Alachua (Newberry) and Pinellas (Palm Harbor) Counties also can now be included based on collections made in 1984. It occurs in greenhouses, nurseries, and grassy fields, where it can be found under boards and potted plants. The slug burrows in soft soil and can enter the root-balls of plants through drainage holes at the base of the containers. To date, few observations on the feeding habits have been made, but Colvin (1962) reported this species eating large amounts of living and decayed leaves. Further, Deisler and Stange (1984) document feeding on living foliage of Epipremnum aureum (Linden \&
Andre) Bunt. Further data on biology and distribution can be found in Baker (1925), Dundee et al. (1965), Dundee (1977), and Deisler and Stange (1984). The slug's velvety black color, which is sometimes interrupted by a pale median stripe, especially in juveniles, and the elongated form of the body provide easy field characters for identification.

3'. Body brown with irregular dark markings, sometimes with dark bands (Fig. 7); anus oval and protected ventrally by anterior flap so that superficial opening is a transverse crescentic slit (Fig. 8) which usually extends beyond the right edge of the retracted foot .... . 4

4. Female opening usually less than $1 / 4$ hyponotal width from foot; dorsum is tan, mottled with black, with long median whitish strip ..... Leidyula (=Veronicella) floridana (Leidy)

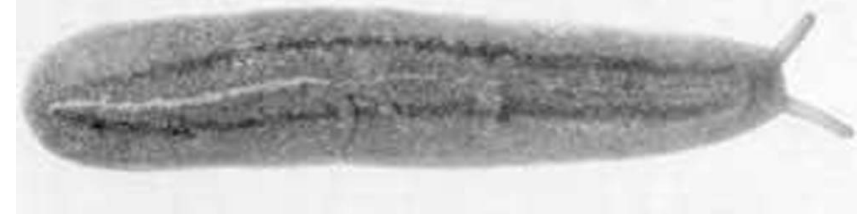

Figure 7. Leidyula floridana. Credits: Division of Plant Industry

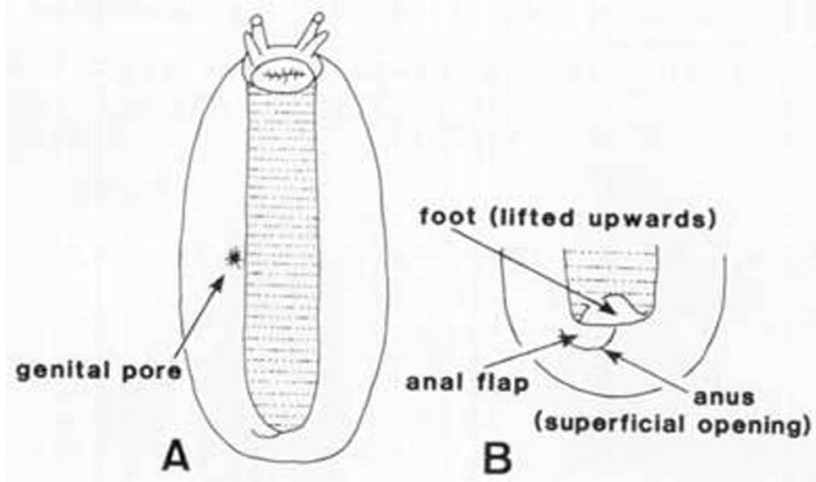

Figure 8. Leidyula floridana - (A) ventral view, (B) anal view. Credits: Division of Plant Industry

This slug is native to the Caribbean (Cuba to Jamaica) and southern Florida. It was first noticed in central Florida in 1968 (Stange 1978) and records are from as far north as Alachua, Duval, and Jefferson Counties, although the slug is also now found in Louisiana (Dundee 1977), and Texas (Neck 1976) suggesting that the species may be even more widespread than available records indicate. It is often found under boards in grassy areas, especially on 
Stenotraphrum secundatum (Walt.) O. Kuntze (St. Augustine grass). No serious economic damage has been reported thus far from Florida, although some damage to beans and tomatoes has been reported (Stange 1978). In Orange County all three species of Veronicellidae slugs were found together under one board, confirming aggregate behavior (Dundee 1975).

4 '. Female opening usually more than $1 / 4$ hyponotal width from foot; dorsum with tint of dead leaf , more or less dark, with or without dorsomedian dark stripe (Fig. 9) . . . . Vaginula plebeia (Fischer) (= Leidyula moreleti (Crosse \& Fischer).

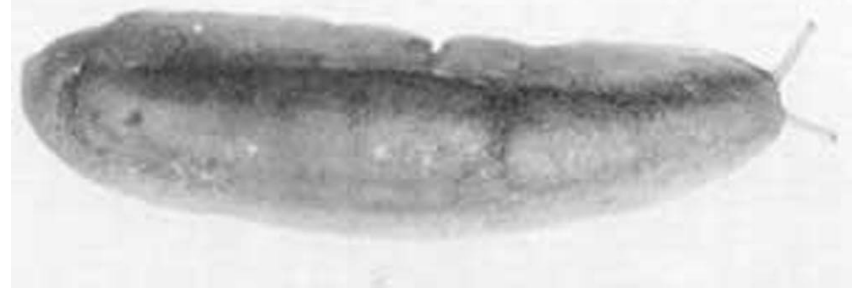

Figure 9. Vaginula plebeia. Credits: Division of Plant Industry

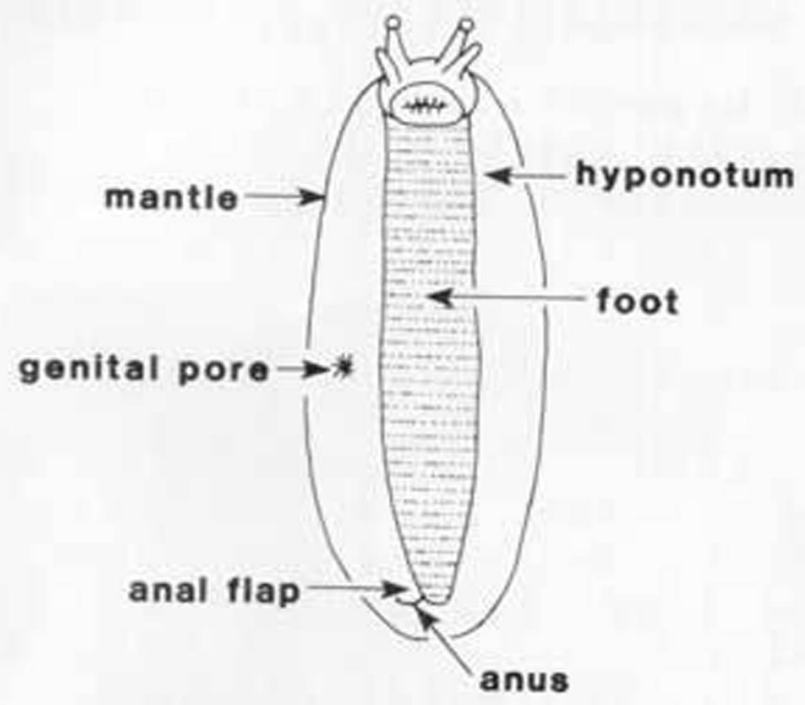

Figure 10. Vaginula plebeia - ventral view. Credits: Division of Plant Industry

This slug is native from Mexico to Nicaragua and has been intercepted at ports in Florida (Burch and Van Devender 1980). It was first identified from established populations from Orange County in 1983, but a study of the DPI collection revealed specimens collected from Orange County in October 1981, and from Jupiter, Palm Beach County, in 1980. Vaginula plebeia superficially resembles the native L. floridana but can be distinguished normally by the position of the female genital pore (more than 1/4 hyponotal width from foot) and by the usual absence of the dorsomedian light stripe found in L. floridana. This species is phytophagus and has caused damage to cacao plants in Tabasco, Mexico, citrus stock in Orange County, Florida, and has been observed feeding on nursery plants such as E. aureum (Deisler and Stange 1984). This species is probably the most destructive threat to Florida agriculture of the three known Florida veronicellid slugs but has less potential for spread since it is non-burrowing and is reported to be viviparous (Baker 1925). Where this slug is established, control measures may be necessary. Records and further data can be obtained from Deisler and Stange (1984).

$\mathbf{5 ( 1 ' ) . ~ B r e a t h i n g ~ p o r e ~ l o c a t e d ~ i n ~ a n t e r i o r ~ h a l f ~ o f ~}$ mantle (Fig. 11); back never keeled; posterior end rounded when viewed from above (Family

Arionidae) Arion circumscriptus Johnson

banded slug: Length 25 to $30 \mathrm{~mm}$. Color pattern is distinctive from the other U.S. introduced species of Arion with the sole of the foot porcelain white. Intercepted in Florida from California on potted Pinus. Can cause considerable damage in greenhouses and vegetable and flower gardens. $A$. ater (L.) which attains a length of more than $70 \mathrm{~mm}$ has also been intercepted in Florida according to Dundee (1974).

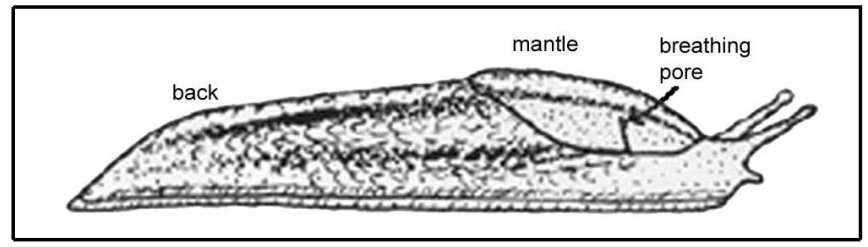

Figure 11. Banded slug. Credits: Division of Plant Industry

$\mathbf{5}^{\prime}$. Breathing pore located in posterior half of mantle (Figs. 5-10); back keeled at least at posterior end which is pointed in dorsal view (Family Limacidae) . . . . 6

$\mathbf{6}\left(5^{\prime}\right)$. Back strongly keeled from the mantle to tip of tail (Fig. 12); mantle granulate with center part bound by groove ..... Milax gagates (Draparnaud) 
greenhouse slug: Length 60 to $70 \mathrm{~mm}$. Widely introduced in the U.S. from Europe, but in Florida only intercepted at ports. This slug usually burrows in the soil and feeds on roots.

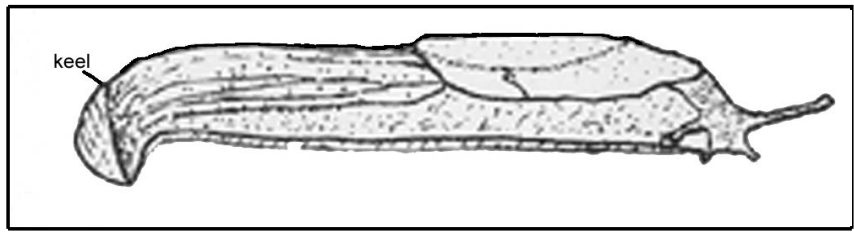

Figure 12. Greenhouse slug. Credits: Division of Plant Industry

6'. Back keeled only near posterior end; mantle concentrically wrinkled, without groove .... . 7

7(6'). Mantle and body with outstanding yellow or black spots (Figs. 13, 14); length $60-70 \mathrm{~mm}$. . . . 8

7'. Mantle and usually back without well defined spots; size $60 \mathrm{~mm}$ or less . . . . 9

8(7). Black-spotted; mucus colorless . . . . Limax maximus Linnaeus

spotted garden slug: Length 80 to $120 \mathrm{~mm}$. Introduced: Massachusetts south to Virginia, west to Oregon and California. This is the largest of the European slugs introduced in the U.S.A. Important pest of gardens, greenhouses, cellars, and mushroom beds. Intercepted in Florida on grape leaves from Tennessee.

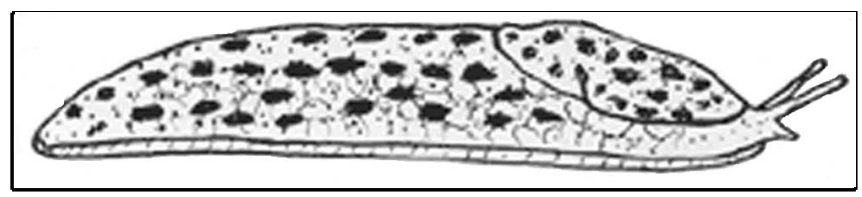

Figure 13. Spotted garden slug. Credits: Division of Plant Industry

8'. Yellow-spotted; mucus yellow . . . . Limax flavus Linnaeus

tawny garden slug: Length 75 to $100 \mathrm{~mm}$. Found in urban and suburban gardens, greenhouses, and other cultivated places. One specimen found in 1965 in Tallahassee. Associated with celery, lettuce, roses. Native to Greece, Italy, Spain.

9(7'). Length $25 \mathrm{~mm}$ or less; mantle situated near middle of body (Fig. 17); mucus colorless . . . . . Deroceras laeve (Müller)

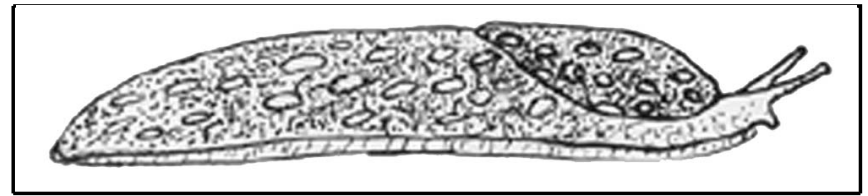

Figure 14. Tawny garden slug. Credits: Division of Plant Industry

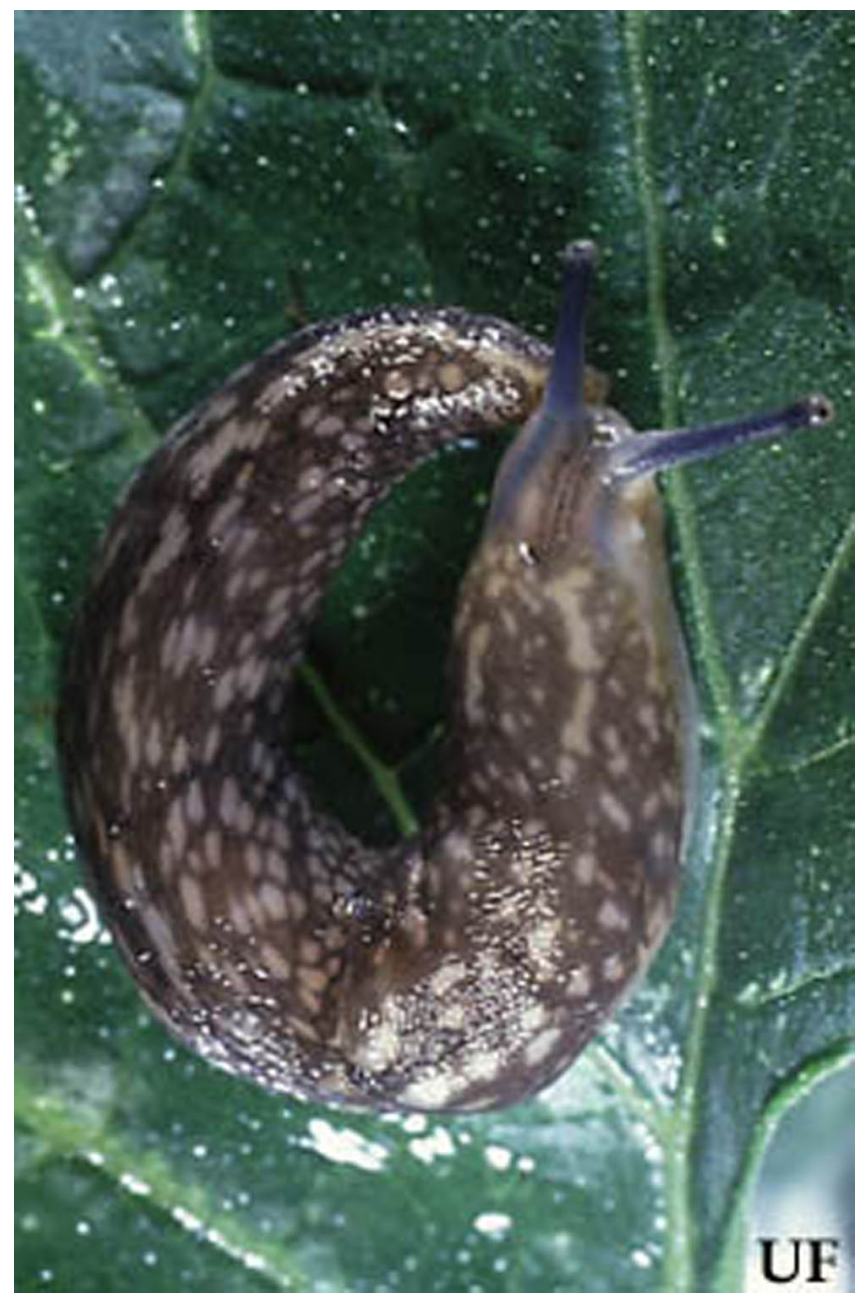

Figure 15. The tawny garden slug, Limax flavus Linnaeus. Credits: John L. Capinera, University of Florida

marsh slug: Smallest of the slugs in Florida. Widespread (Arctic to Central America) and highly adaptive. Feeds on great variety of plants in cultivated areas as well as in swamps, forests, etc. Can survive subfreezing temperatures (Getz 1959). Native throughout Florida from the Keys to Pensacola.

9'. Length $35 \mathrm{~mm}$ or more; mantle situated forward near head (Figs. 13, 15) . . . . 10

10(9'). Exudes milky adhesive slime when irritated; breathing pore surrounded by pale ring; 


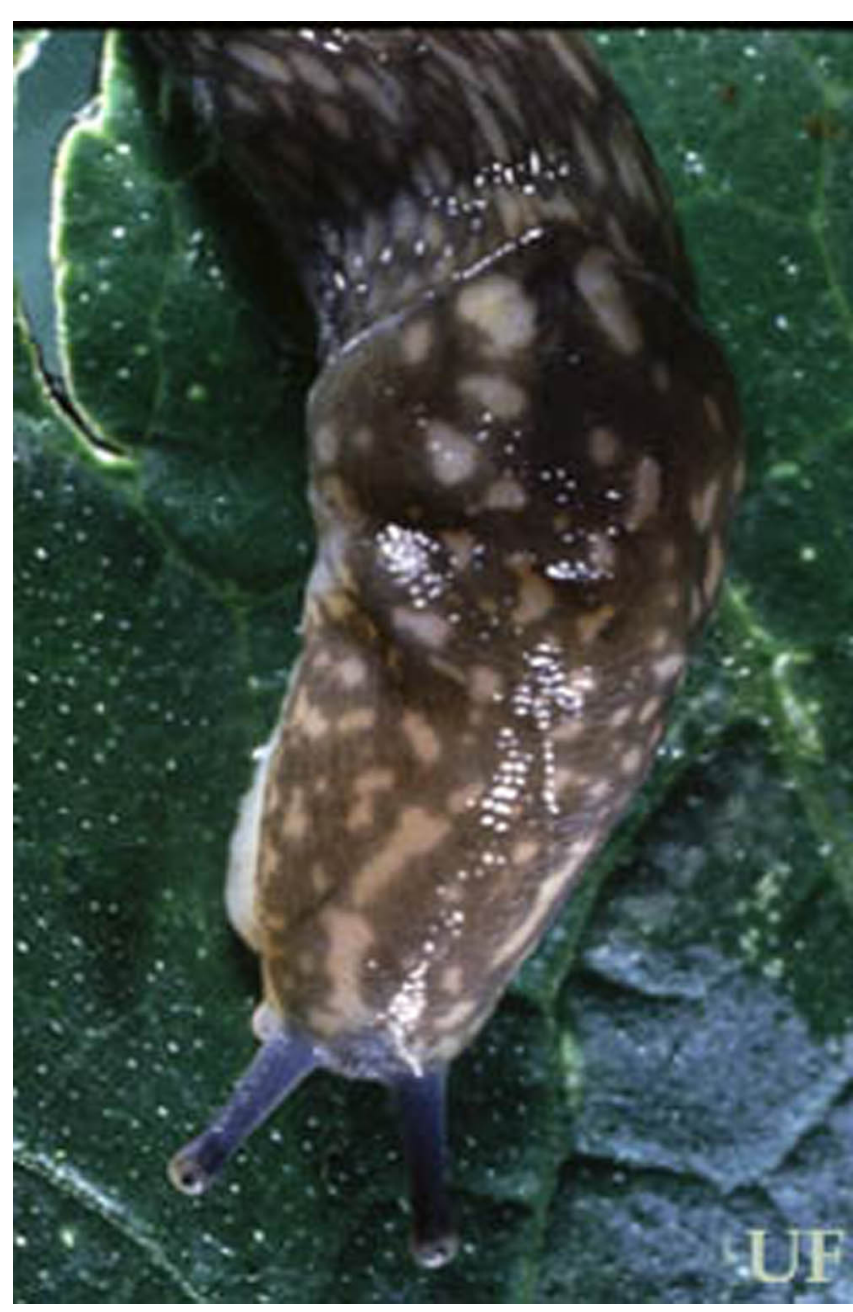

Figure 16. Detail of the mantle of $L$. flavus Linnaeus. Credits: John L. Capinera, University of Florida

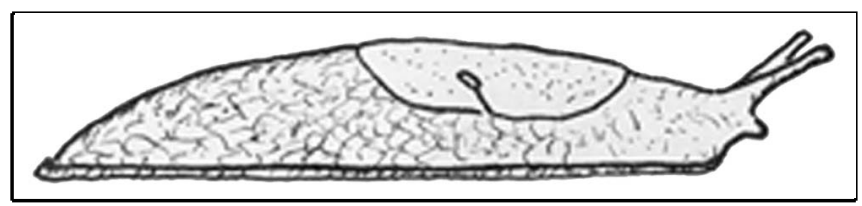

Figure 17. Marsh slug. Credits: Division of Plant Industry

usually without well defined dark longitudinal bands . .... Deroceras reticulatum (Müller)

gray garden slug: Length 35 to $50 \mathrm{~mm}$. Feeds on variety of plants below and above the soil surface such as young corn, cabbage, tomatoes, peas, strawberries, also ornamentals, mushrooms, and decaying vegetation. Widespread in U.S. except in Gulf states. Intercepted in Florida many times, mostly on ornamentals.

10'. Exudes watery slime; breathing pore not surrounded by pale ring with well defined dark

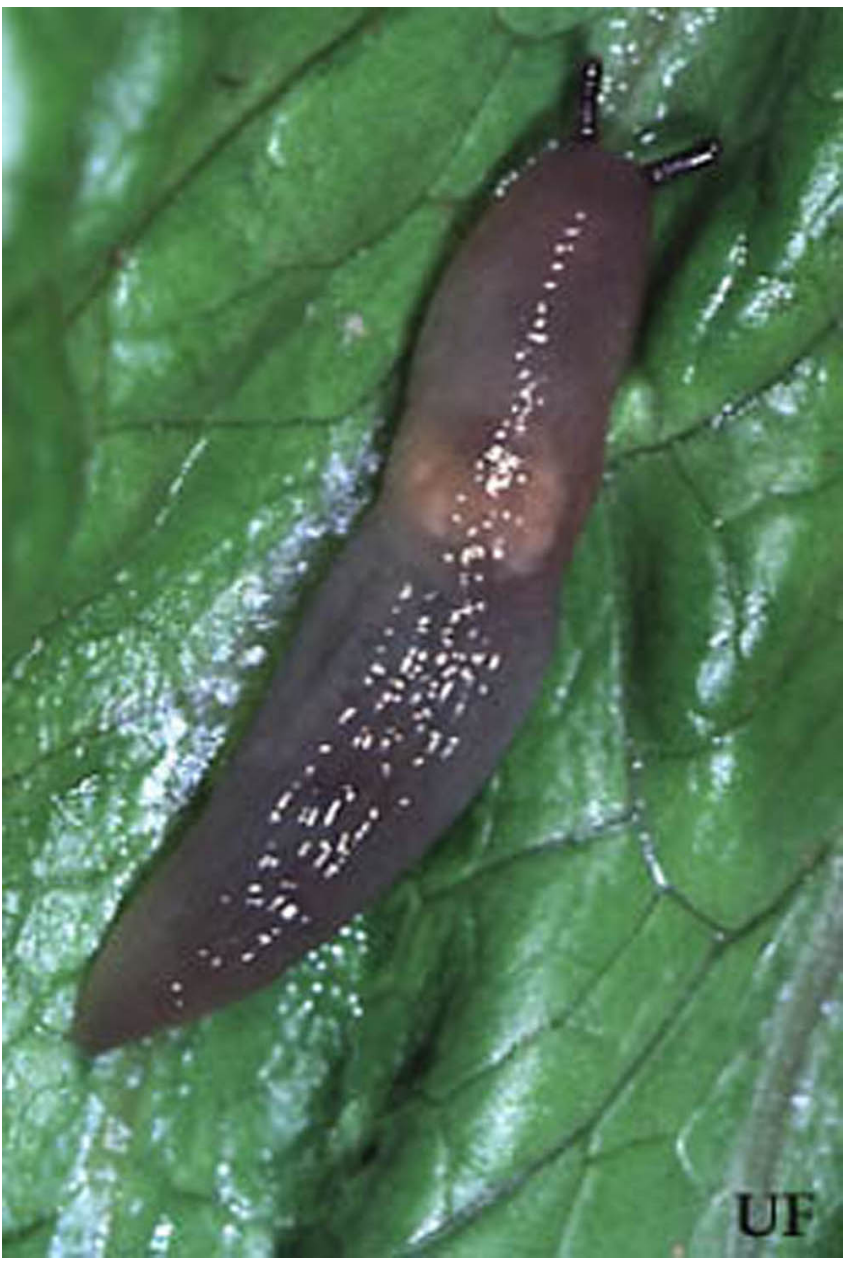

Figure 18. The marsh slug, Deroceras laeve (Müller). Credits: Paul. M. Choate, University of Florida

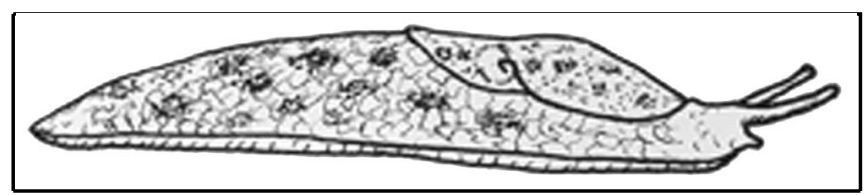

Figure 19. Gray garden slug. Credits: Division of Plant Industry

longitudinal bands on mantle and back ..... Lehmannia poirieri (Mabille)

Length 50-60 mm. Introduced into New York, Arizona, California. Intercepted in Florida several times on Hydrangea from California. Recorded from Pensacola (Dundee 1974).

\section{Economic Importance}

Little slug damage has been reported in Florida, but elsewhere some of the introduced European slugs have caused great damage on many vegetable plants in urban and suburban gardens and in cellars where 


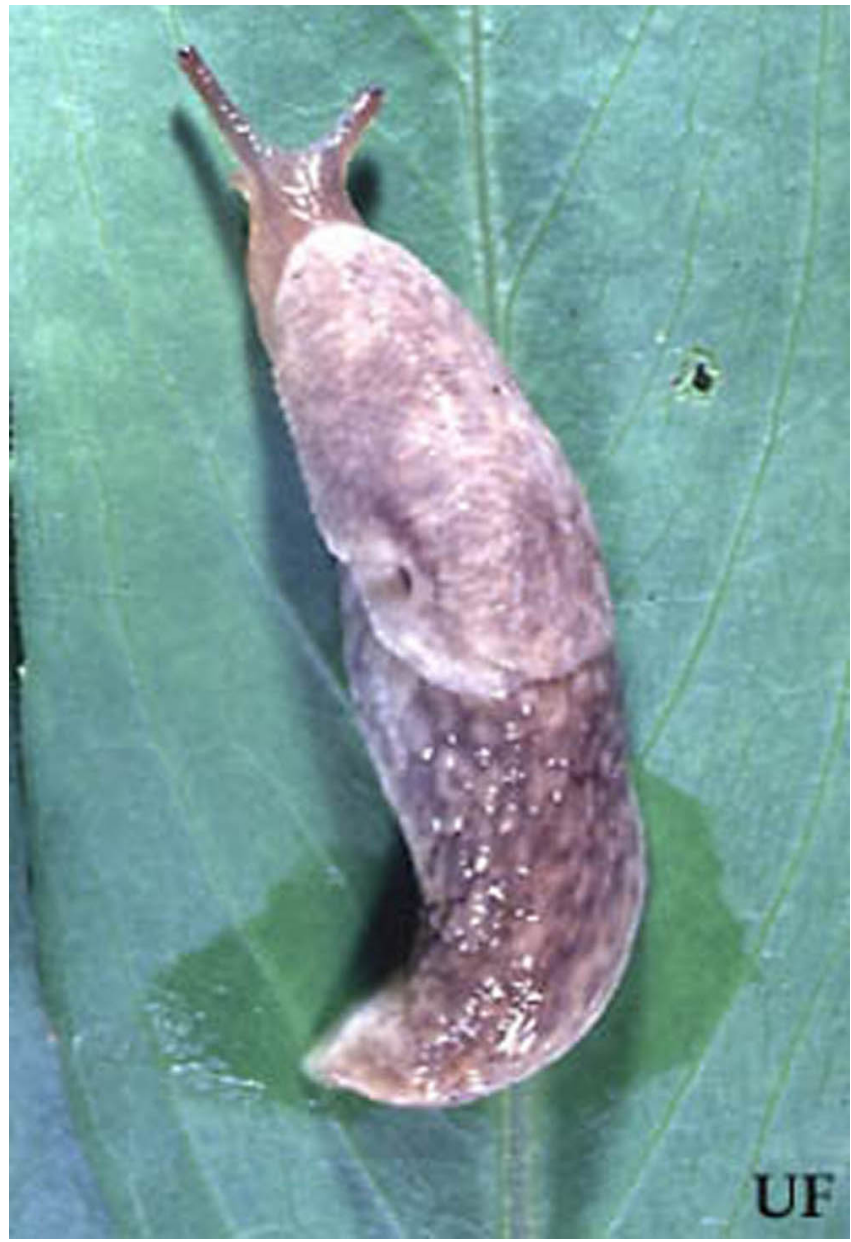

Figure 20. The gray garden slug, Deroceras reticulatum (Müller). Credits: John L. Capinera, University of Florida

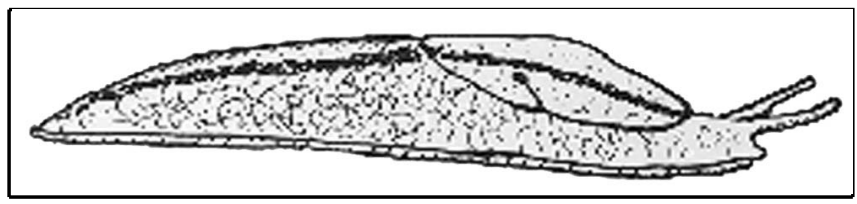

Figure 21. Lehmannia poirieri (Mabille) slug. Credits: Division of Plant Industry

they may attack potatoes. They are also fond of mushrooms. They also cause concern for the unsightly slime trails on ornamentals. They may transmit plant pathogens (Western et al. 1964). Little is known of their significance as intermediate hosts of disease parasites of animals (Chichester and Getz 1068). As a precaution, slugs should not be picked with bare hands. Introduced slugs may disturb the natural ecological balance in some areas, leading to the disappearance of native species.

\section{Management}

Natural enemies are relatively few (Stephenson and Knutson, 1966). Some birds, especially ducks, feed on slugs. Predator snails such as Euglandina rosea (Férussac) attack slugs. Few predaceous insects attack slugs, but the larvae of Lampyridae and adult Carabidae (Coleoptera) do so occasionally. There are some dipterous parasites (especially Sciomyzidae) (Trelka and Foote 1970). A few fungous diseases are known. Adverse climatic conditions (e.g., dry, hot weather or excessive rains) serve to lessen depredations but do not appear to be of great significance. The rather poor slug fauna of Florida may be due to historic factors or perhaps to some natural factor as soil types. Clean surroundings will aid in controlling slug populations, and removal of boards, sacks, piles of brush, and other debris will limit slug numbers. When chemical control is indicated, the use of baits is recommended in commercial greenhouses.

Insect Management Guides for Ornamentals

Insect Management Guide for Vegetables

\section{Selected References}

Baker HB. 1925. North American Veronicellidae. Proceedings of the Academy of Natural Science, Philadelphia 77: 157-183.

Burch, JB 1960. Some snails and slugs of quarantine significance to the United States. U.S. Dept. Agr. Res. Ser. 82: 1-73.

Burch, JB 1962. How to know the eastern land snails. The Pictured-Key Nature Series. Wm. C. Brown Co., Dubuque, Iowa. 214 p.

Burch JB, Van Devender AS. 1980.

Identification of eastern North American land snails: The Prosobranchia, Opisthobranchia and Pulmonata (Actophila). Walkerana 1: 33-80.

Chichester, LF, and Getz LL. 1968. Terrestrial slugs. Biologist 1: 148-166.

Colvin TA. 1962. Observations on a slug, Vaginulus sp., in captivity. Louisiana Academy of Science 25: 122-135. 
Deisler JE, Stange LA. 1984. The Veronicellid slugs of Florida. Florida Department of Agriculture and Consumer Services, Division of Plant Industry, Entomology Circular 241:1-4.

Dundee, DS 1974. Catalog of introduced molluscs of Eastern North America (North of Mexico). Sterkiana 55: 1-37.

Dundee, DS 1977. Observations of the veronicellid slugs of the Southern United States. Nautilus 91: 108-114.

Dundee DS, Stutts BS, Hermann PW. 1965. Preliminary survey of a possible molluscan pest in the southern United States. Ecology 46: 192-193.

Dundee DS, Tizzard M, Traub M. 1975. Aggregative behavior in Veronicellid slugs. Nautilus 89: 69-71.

Dundee DS, Watt P. 1961. Louisiana land snails with new records. Nautilus 75: 79-82.

Getz, LL 1959. Notes on the ecology of slugs: Arion circumscriptus, Deroceras reticulatum and $D$. laeve. Amer. Midl. Nat. 61: 485-498.

Gillmore R. 1982. On pest detection survey. Plant Industry News, Florida Department of Agriculture and Consumer Services 24: 8-12, 14.

Hermann, P.W., and D.S. Dundee. 1969. Notes on a light colored specimen of Philomycus carolinianus (Bosc). Nautilus 82: 133-137.

Karlin, E.J., and J.A. Naegele. 1958. Slugs and snails in New York greenhouses. Cornell Ext. Bull. 1004: 2-16.

Karlin, E.J., and C. Bacon. 1961. Courtship, mating and egg laying in the Limacidae. Trans. Amer. Microscop. Soc. 80: 399-406.

Key, H.W. 1902. On the mucus-thread of land-slugs. J. Conch. 10: 92-103, 153-165.

Lovett, A.L., and A.B. Black. 1920. The gray garden slug with notes on allied forms. Oregon Agr. Exp. Sta. Bull. 170: 1-43.
Neck RW. 1976. Adventive land snails in the Brownsville, Texas area. Southwestern Naturalist 21: 135-36.

Peterellis LS, Dundee DS. 1969. Veronicella ameghini (Gastropods): Reproductive, digestive and nervous systems. Transactions of the American Microsc. Society 88: 547-558.

Pilsbry, H.A. 1968. Land Mollusca of North America. Acad. Nat. Sci. Philad. Monogra. 3, Vol. 2, pt. 2: i-xlvii, p. 521-1113.

Stange LA. 1978. The slugs of Florida. Florida Department of Agriculture and Consumer Services, Division of Plant Industry, Entomology Circular 197, $4 \mathrm{p}$.

Stephenson, J.W., and L.V. Knutson. 1966. A resume of recent studies of invertebrates associated with slugs. J. Econ. Ent. 59: 356-360.

Thome JW. 1975. Os generos da Familia Veronicellidae Nas Americas (Molluscs: Gastropoda). Iheringia (Zool.) 48: 3-56.

Trelka, D.G., and B.A. Foote. 1970. Biology of slug-killing Tetanocera (Dipt. Sciomyzidae). Ann. Ent. Soc. Am. 63: 877-895.

Wester, R.E., R.W. Goth, and R.E. Webb. 1966. Transmission of downy mildew of lima beans by slugs. Phytopathology 54: 749.

White, W.H., A.C. Davis. 1953. Land slugs and snails and their control. U.S. Dept. Agr., Farmers' Bull. 1895 (Revised Edition): 1-8. 